\title{
Meta-analyses of the effect of flossing on ankle range of motion and power jump performance
}

Authors' Contribution: A Study Design B Data Collection C Statistical Analysis D Data Interpretation E Manuscript Preparation

F Literature Search G Funds Collection

\author{
Anna Pisz ${ }^{1 \mathrm{ABCDEF}}$, Katerina Kralova ${ }^{1}$ BE, Dusan Blazek ${ }^{1 \mathrm{BCF}}$, Artur Golas ${ }^{2 \mathrm{AD}}$, \\ Petr Stastny ${ }^{1}$ CDG \\ ${ }^{1}$ Faculty of Physical Education and Sport, Charles University in Prague, Czech Republic \\ 2 The Jerzy Kukuczka Academy of Physical Education in Katowice, Poland
}

\section{abstract}

Key words: medical flossing, range of motion, jump performance.

\section{article details}

Article statistics:

Full-text PDF:

Copyright

Indexation:

Conflict of interests: Corresponding author:

Open Access License:

Decreased ankle range of motion (ROM) leads to many disorders, ranging in severity from gait abnormalities to knee and pelvis injuries. Therefore, maintaining full ankle ROM is very important, especially for athletes, for whom ankle ROM may affect their results during competitions. Medical flossing is a technique used by physiotherapists to improve ROM. The aim of this review was to investigate the effect of medical flossing on ankle ROM according to the results in previous studies.

The search was conducted with the following key words individually and/or in combinations: range of motion, flossband, mobility bands, vascular occlusion, flossing bands, compression, voodoo floss, and tack floss.

From the identified 5600 articles, only 4 studies were included in this systematic review. The results showed that the mean difference in ROM after treatment was $1.20 \mathrm{~cm}$ (Hedge's g $=0.31, \mathrm{p}<0.01,12=89 \%$ ).

There is evidence showing that the application of flossing can be beneficial to increase the ROM. Moreover, some of the studies confirmed a positive impact of flossing on jump performance; nonetheless, data to confirm this effect in this review are insufficient.

Word count: 2,844; Tables: 2; Figures: 3; References: 32

Received: April 2020; Accepted: May 2020; Published: June 2020

http://www.balticsportscience.com

(c) Gdansk University of Physical Education and Sport, Poland

Celdes, Clarivate Analytics Emerging Sources Citation Index (ESCI), CNKI Scholar (China National Knowledge Infrastructure), CNPIEC, De Gruyter - IBR (International Bibliography of Reviews of Scholarly Literature in the Humanities and Social Sciences), De Gruyter - IBZ (International Bibliography of Periodical Literature in the Humanities and Social Sciences), DOAJ, EBSCO - Central \& Eastern European Academic Source, EBSCO - SPORTDiscus, EBSCO Discovery Service, Google Scholar, Index Copernicus, J-Gate, Naviga (Softweco, Primo Central (ExLibris), ProQuest - Family Health, ProQuest - Health \& Medical Complete, ProQuest - Illustrata: Health Sciences, ProQuest - Nursing \& Allied Health Source, Summon (Serials Solutions/ProQuest, TDOne (TDNet), Ulrich's Periodicals Directory/ulrichsweb, WorldCat (OCLC)

This research was funded by Charles University grant UNCE HUM 032 and student support SVV 260466.

Authors have declared that no competing interest exists.

Anna Pisz, Faculty of Physical Education and Sport, Charles University in Prague, Jose Martiho 269, 16252 Prague, Czech Republic. Phone: +420703952913, E-mail: piszan@gmail.com

This is an open access article distributed under the terms of the Creative Commons Attribution-Non-commercial 4.0 International (http://creativecommons.org/licenses/by-nc/4.0/), which permits use, distribution, and reproduction in any medium, provided the original work is properly cited, the use is non-commercial and is otherwise in compliance with the license. 


\section{INTRODUCTION}

Flexibility is the ability to move a joint through its full range of motion (ROM) with control. A lack of mobility in one joint can lead to injuries and pain along the kinetic chain [1]. By increasing ROM, we may be able to enhance performance and reduce the risk of injury, and athletes should possess a level of flexibility that is appropriate for their chosen activities [2]. Moreover, increased ROM leads to improvements in vertical jumps [3]. Currently, there are many methods available to acutely increase ROM, one of which is medical flossing, also known as voodoo flossing [4]. It is assumed that the possible mechanisms of improvements in ankle ROM due to flossing are connected with fascial shearing and blood-flow restriction. Perhaps, this is a similar process to that of blood-flow restriction training through which increased amounts of growth hormones and catecholamine responses arise, increasing muscle forces and contractility and the efficiency of excitation-contraction coupling in the muscles [5, 6]. Fascia is a tough connective tissue that is present throughout the body in a threedimensional web from head to toe. Fasciae are ubiquitous, surrounding every muscle, bone, nerve, blood vessel and organ at the cellular level. Generally, the fascial system provides support, stability and cushioning. It is also important for locomotion and dynamic flexibility due to muscle involvement, and it is considered the main contributor to proprioception in the body [7, 8]. Fasciae play the main role in movement coordination and muscle interaction. An insufficient amount of flexible fasciae can lead to weakened muscles and poor muscular biomechanics, which lead to a decreased ROM, altered structural alignment and reduced endurance and motor coordination [9, 10]. Shearing caused by rubber bands might decrease the stiffness of the fascia, the main effect of which is an increase in ROM.

As mentioned above, flossing may have similar mechanisms to ischemic preconditioning/blood-flow occlusion/restriction training. In addition to the hormonal response it yields, ischemic preconditioning has been shown to improve muscle contraction efficiency, possibly by increasing muscle forces and contractility [11], and/or to improve the quality of excitation-contraction coupling [12]. Flossing can be applied to any joint or muscle in the body. However, because the ankle joint is important for walking, jumping and landing, most of the previous studies have focused on the ankle. The ankle is a complex part of the human body [13]. Proper biomechanical function of the ankle is required for the lower extremities to function normally [14]. Changes in ROM can lead to many dysfunctions, both in normal daily living, as ankle dorsiflexion (DF) is required during walking [15], and during sport activities, as DF is an important strategy used to absorb shock when landing after a jump [16, 17]; limitations in the movement of the ankle lead to restricted knee flexion displacement and knee valgus displacement during landing and squatting. All these issues may contribute to increased anterior cruciate ligament (ACL) injury risk, patellofemoral pain and other lower-limb injuries [17-22].

There is a limited amount of research on flossing, and no review articles have been conducted. Kiefer et al. [23] assessed the effect of flossing on glenohumeral flexion in child's posture. The results showed that there were no significant differences between the flossing and control groups; however, participants indicated more significantly perceived benefits from the intervention in terms of mobility. Moreover, the glenohumeral joint is considered difficult to wrap with tape, unlike the ankle, which is the main point of interest in this field. 
Although an effect of flossing has been documented, it has not been determined how large impact can be expected with this method; therefore, the aim of this study was to conduct a meta-analysis on the effects of flossing on aspects of performance.

\section{MATERIAL AND METHODS}

\section{SEARCH STRATEGIES}

The review included studies that examined the effects of flossing on the ankle range of motion. The articles in the Scopus, PubMed, PEDro and Google Scholar databases were searched. The search took place in November 2019, and the results were not restricted by dates. The databases were searched by using the following keywords: range of motion, flossband, mobility bands, vascular occlusion, flossing bands, compression, voodoo floss, and tack floss. These key words were used individually and/or in combination.

\section{STUDY SELECTION}

The inclusion criteria for the studies in this review were as follows: the study contained a research question regarding the influence of flossing on the ankle range of motion; the ROM test was performed with the standard methodology, with the results reported in $\mathrm{cm}$; and the study was published in English. The exclusion criteria were the text not in English, poor methodological design or measured parameters.

\section{QUALITATIVE COMPARISON}

Qualitative analyses were performed using RevMan version 5.3 (Copenhagen). Weighted means was used to calculate the flossing effect among different studies and e. Hedges' g was consequently chosen for effect size. I2 was used to assess heterogeneity.

\section{RESULTS}

The search process is presented in Figure 1. In total, 5503 records were identified with search keywords in the Scopus database, and 132 records were identified from other sources. After the duplicate articles were removed, a total of 5600 articles remained. After the abstracts were screened, 28 articles remained, and 22 articles were excluded because they were not suitable for a systematic review. The full texts of six articles were used to determine their eligibility (Supplementary material 1), and two of them were not suitable for qualitative comparison with other studies. In total, 4 records were included in the meta-analysis. In total, those 4 documents involved 145 participants, where all studies used weight-bearing lunge test (WLBT). One article was missing a control group because it used a crossover design. The remaining study [24] used the contralateral leg, which did not undergo the flossing treatment, for comparison, or the participants attended another session to obtain control group results.

Table 1 and Figure 2 show the main results of the included studies, where all authors of these studies concluded that flossing increases the ankle range of motion. Table 2 and Figure 3 show the reported changes in the included studies. The weighted mean difference in ROM after treatment was $1.20 \mathrm{~cm}$ 
(Hedge's $g=0.31$, CI [0.086, 0.529], $\mathrm{Z}=2.719, \mathrm{p}<0.01, \mathrm{I} 2=89 \%$ ). The control groups did not show any differences between pre and post treatment. The same result was confirmed in the two other studies, where one was a single case and the other reported the increased ROM in degrees [25, 26]. The jump performance increase has been reported in two studies performed by Driller and one study performed by Mills [24, 27, 28]. In his first study Driller measured jump height and velocity which makes it incomparable with the other two studies, where peak force was measured during Counter Movement Jump (CMJ). Results have shown $4 \mathrm{~cm}$ improvement in the jump height and 0.15 (m.s-1) jump velocity improvement [24]. In another Driller study, the flossing impact on CMJ peak force was measured after application. Results have shown increasing of the peak force in the following order: $69 \pm 67 \mathrm{~N}$ after 5 minutes $(d=0.16), 56 \pm 70 \mathrm{~N}$ after 15 minutes $(d=0.13), 135 \pm 148 \mathrm{~N}$ after 30 minutes $(d=0.32)$ and $89 \pm 101 \mathrm{~N}$ after 45 minutes $(d=0.21)$ [27]. Mills also compared CMJ peak force pre and post values after 5 and 30 minutes, which resulted in $90 \pm 117 \mathrm{~N}(\mathrm{~d}=0.28 \pm 0.45)$ improvement after 5 minutes after floss application, and $-37 \pm 77 \mathrm{~N}(\mathrm{~d}=-0.12 \pm 0.30)$. Overall, those results showed a beneficial impact of flossing application on the jump performance.

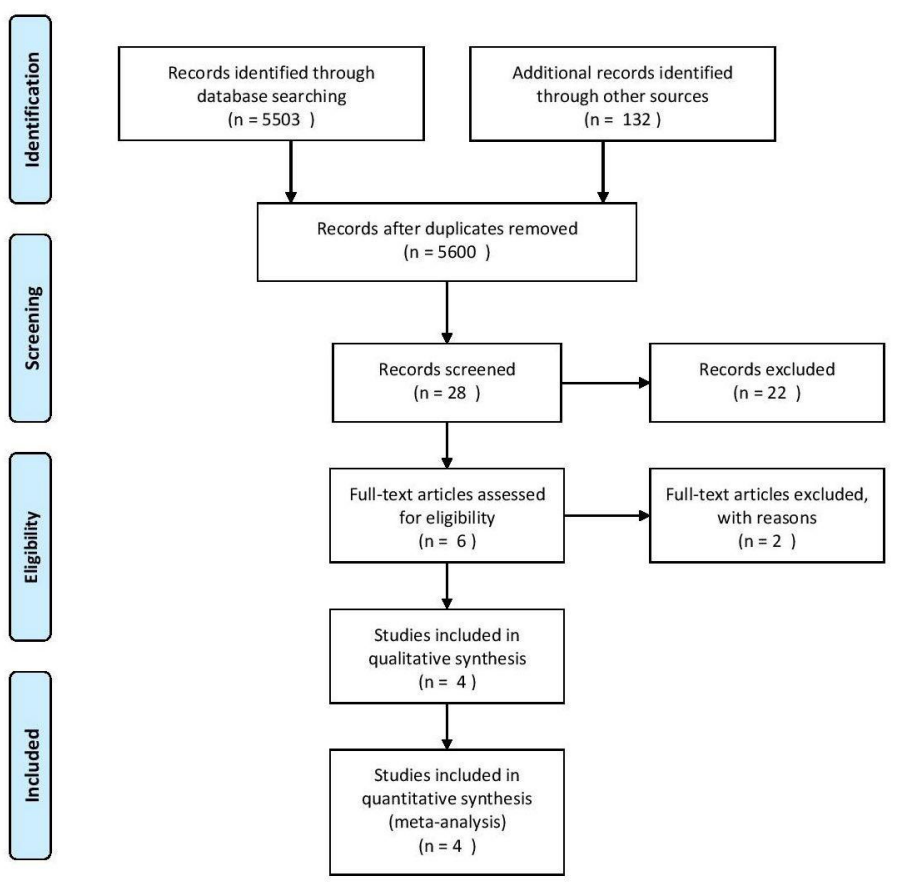

Fig. 1. PRISMA flowchart of the search process

Table 1. Effects of flossing on ankle range of motion $(\mathrm{cm})$

\begin{tabular}{lccccc}
\hline References & $\mathrm{n}$ & $\begin{array}{c}\text { Preflossing } \\
\text { Mean } \pm \text { SD }\end{array}$ & $\begin{array}{c}\text { Postflossing } \\
\text { Mean } \pm \text { SD }\end{array}$ & $\begin{array}{c}\text { Pre control } \\
\text { Mean } \pm \text { SD }\end{array}$ & $\begin{array}{c}\text { Post control } \\
\text { Mean } \pm \text { SD }\end{array}$ \\
\hline Driller [24] & 52 & $10.9 \pm 6$ & $12.7 \pm 6.5$ & $11.4 \pm 6.7$ & $11.6 \pm 6.5$ \\
Driller [27] & 69 & $8.9 \pm 3.6$ & $9.7 \pm 3.7$ & $8.3 \pm 3.3$ & $8.3 \pm 3.7$ \\
Mills [28] & 14 & $9.9 \pm 3.4$ & $10.3 \pm 3.5$ & $9.7 \pm 4.0$ & $10.1 \pm 3.5$ \\
Ross [22] right leg & 10 & $7 \pm 1.5$ & $8.15 \pm 1.5$ & - & - \\
Ross [22] left leg & 10 & $6.7 \pm 2.7$ & $8.65 \pm 2.03$ & - & - \\
\hline
\end{tabular}


Baltic Journal of Health and Physical Activity 2020; 12 (2): 19-26

Journal of Gdansk University of Physical Education and Sport

e-ISSN 2080-9999

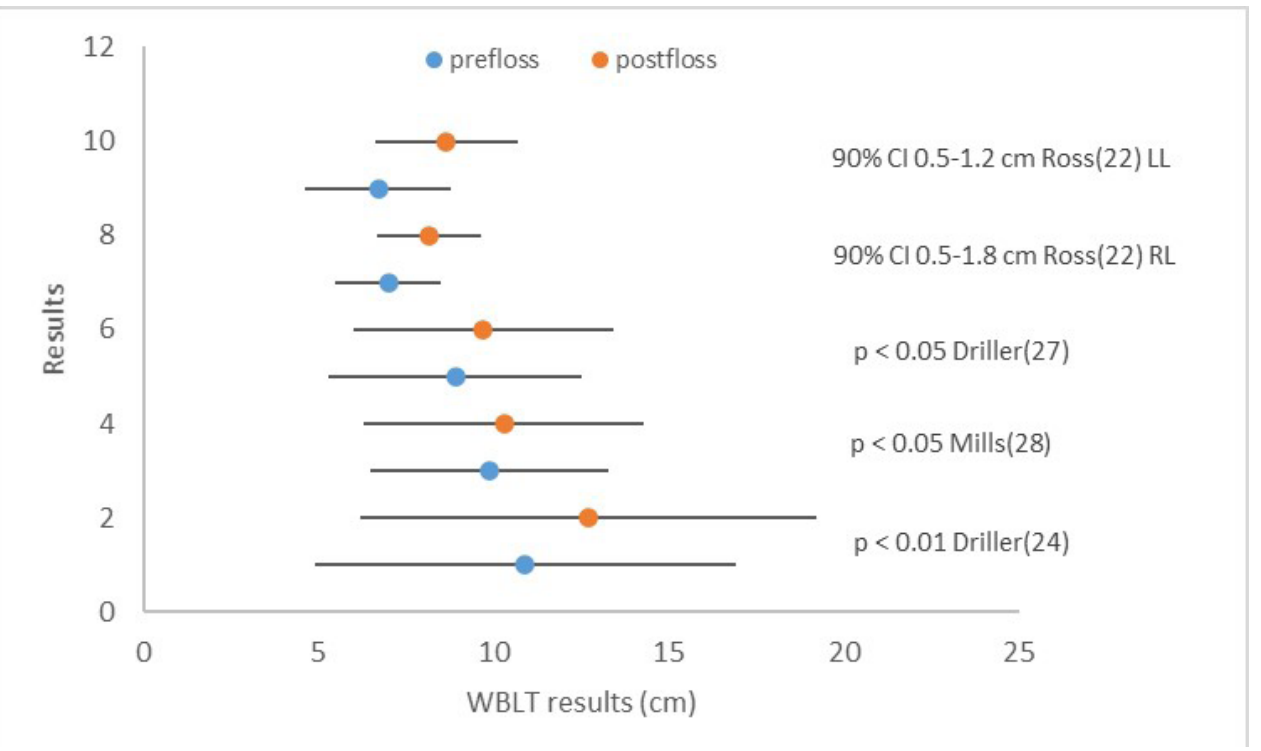

Fig. 2. Comparison of the preflossing and postflossing results

Table 2. Effects of flossing on ankle range of motion $(\mathrm{cm})$

\begin{tabular}{|c|c|c|c|}
\hline References & $n$ & $\begin{array}{c}\text { Difference between } \\
\text { pre- and postflossing }(\mathrm{cm})\end{array}$ & $\begin{array}{c}\text { Effect size/ } \\
\text { confidence interval }\end{array}$ \\
\hline Driller [24] & 52 & 1.8 & 0.29 \\
\hline Driller [27] & 69 & 0.8 & 0.2 \\
\hline Mills [28] & 14 & 0.4 & $95 \% \mathrm{Cl} 0.01-0.18 \mathrm{~cm}$ \\
\hline Ross [22] right leg & 10 & 1.15 & $90 \% \mathrm{Cl} 0.5-1.8 \mathrm{~cm}$ \\
\hline Ross [22] left leg & 10 & 1.95 & $90 \% \mathrm{Cl} 0.5-1.2 \mathrm{~cm}$ \\
\hline Weighted mean & & 1.20 & \\
\hline
\end{tabular}

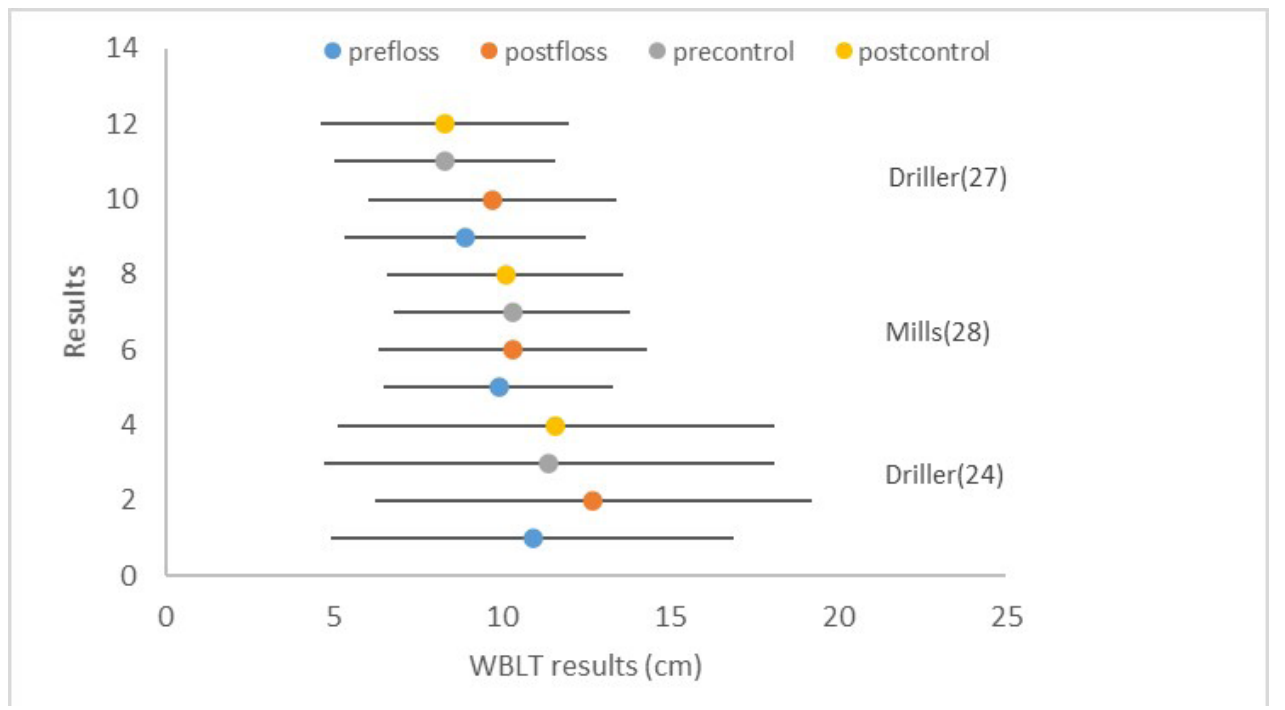

Fig. 3. Comparison of all pre- and postflossing outcome measures 


\section{DISCUSSION}

In the first quantitative systematic review of the flossing effect on the ankle range of motion, the evidence shows a small beneficial effect of flossing. Some of those papers reported few indicators; for instance, Driller and Mills assessed countermovement jumps (CMJs) after flossing, and in both studies, the outcomes yielded positive results. Based on these results, it can be assumed that flossing improves jump performance; however, more research needs to be conducted. Moreover, flossing can be applied to any part of the body that has fascia, but for now, most of the articles have focused on the ankle. This focus should be broadened, and new parts of the body should be explored to discover the potential of flossing. A study made by Hodeaux was assessed the impact of flossing application on the elbow ROM [29], and in another study flossing was applied to the glenohumeral joint to assess its efficiency [23].

Since improvement in the ankle ROM at the $0.6 \mathrm{~cm}$ level was considered large [30], the change in dorsiflexion measured with WBT at the $1.2 \mathrm{~cm}$ level can be considered a large increase in ankle mobility. On the other hand, the most significant limitation of this study is the differences in studies participants: in two studies, they were recreational athletes; in another study, they were professional athletes; and in the last study, the participants were individuals free from lower extremity injuries for 3 months. However, we can assume that flossing is beneficial to participants at different performance levels.

Driller et al. suggested the beneficial influence of flossing on the ankle ROM and jump performance. In his first article, he assessed 52 recreational athletes by using the WLBT, measuring ankle DF and plantar flexion (PF) with a goniometer and measuring single vertical jump height and velocity with a Gymaware device. The results showed a significant improvement in all test measures preto postintervention $(p<0.01)$ [24]. In his second study, 69 recreational athletes performed the WBLT, countermovement jump (CMJ) and a $15 \mathrm{~m}$ sprint test (SPRINT) before and up to 45 minutes after the application of the flossband to both ankles $(n=38)$, and the control group did not receive flossing $(n=31)$. There were significant differences ( $p>0.05$ ) between the FLOSS and CON groups in the results for the WBLT, CMJ and $15 \mathrm{~m}$ sprint [27]. Stevenson et al. measured the influence of flossing in 5 male recreational athletes. They used a goniometer and the WBLT to obtain the results, which showed that DF significantly improved in the flossing group compared with the control group [26].

A group of scientists from New Zealand determined the effect of flossing in 14 professional male rugby union athletes (mean \pm SD: age; $23.9 \pm 2.7$ ) [28]. They applied flossing for two minutes to both ankles and performed the same measurements without flossing on a separate day for the control data. The WBLT, CMJ and 20-meter sprint were performed, and the outcomes were assessed 5 minutes after and 30 minutes after application. The results showed a small but non-significant ( $\mathrm{p}>0.05$ ) benefit in the FLOSS group compared with the CON group for the CMJ at 5 minutes post-intervention $(\mathrm{d}=0.28)$ and for sprinting for 10 meters $(d=-0.45)$ and 15 meters $(d=-0.24)$ at 30 minutes after the intervention [28]. Therefore, the results of flossing on jump performance should be more clearly evaluated.

In a study performed by Reid et al. [30], improvement in the ankle ROM was measured by the mobilization-with-movement (MWM) technique on talocrural joints. Dorsiflexion was assessed using a weight-bearing lunge test. They used 
a crossover design with randomized allocation to either a sham mobilization group or the MWM technique group. The results showed that the change in dorsiflexion following the MWM technique $(0.63 \pm 0.89 \mathrm{~cm})$ was significantly larger $(p=0.02)$ than the change following the sham technique $(0.18 \pm 0.35$ $\mathrm{cm})$. Vicenzino et al. [31] measured the changes in the posterior talar glide and dorsiflexion of the ankle after mobilization with movement (MWM) in individuals with recurrent ankle sprains. The results showed that both the weight-bearing and non-weight-bearing MWMs significantly improved dorsiflexion by $26 \%$ $(\mathrm{p}<0.17)$ in a WBLT test. Dorsiflexion before treatment was $4.2 \pm 1.6 \mathrm{~cm}$ for weight-bearing WMWs and $4.3 \pm 1.9 \mathrm{~cm}$ for non-weight-bearing MWMs, and those after treatment were $4.8 \pm 1.5 \mathrm{~cm}$ for WB_MWMs and $4.8 \pm 1.5 \mathrm{~cm}$ for NWB_MWMs, which yielded $0.6 \mathrm{~cm}$ of improvement for WB WMWs and $0.5 \mathrm{~cm}$ of improvement for NWB_WMWs.

Weight Bearing Lunge Test (WBLT) is a very reliable test to measure the dorsiflexion (DF) range of movement in the ankle joint [32]. It does not require any tools, and the methodology is not complicated; therefore, it is a popular choice among researchers to assess the ankle ROM.

\section{CONCLUSIONS}

After analyzing all the results and comparing flossing to other methods, it can be assumed that flossing is a useful method to acutely increase ROM. It can be used by physiotherapists during rehabilitation for individuals with ankle ROM limitations and athletes as a part of warm-up, especially before exercises that require a full ankle ROM, i.e., squats, CMJ. Moreover, it seems to be a good technique for individuals who participate in sports that involve jumping, e.g., volleyball and basketball; two studies proved that flossing could improve jump performance.

\section{REFERENCES}

[1] Storm JM, Wolman R, Bakker EWP, Wyon MA. The relationship between range of motion and injuries in adolescent dancers and sportspersons: A systematic review. Front Psychol. 2018;9:287. https:// doi.org/10.3389/fpsyg.2018.00287

[2] Andersen JC. Flexibility in performance: Foundational concepts and practical issues. Athl Ther Today. 2006;11(3):9-12. https://doi.org/10.1123/att.11.3.9

[3] Clansey A, Lees A, editors. Changes in lower limb joint range of motion on countermovement vertical jumping. ISBS-Conference Proceedings Archive; 2010

[4] Starrett K, Cordoza G. Becoming a supple leopard: The ultimate guide to resolving pain, preventing injury, and optimizing athletic performance. Victory Belt Publishing; 2013.

[5] Takarada Y, Nakamura Y, Aruga S, Onda T, Miyazaki S, Ishii N. Rapid increase in plasma growth hormone after low-intensity resistance exercise with vascular occlusion. J Appl Physiol. 2000;88(1):61-5. https:// doi.org/10.1152/jappl.2000.88.1.61

[6] Reeves GV, Kraemer RR, Hollander DB, et al. Comparison of hormone responses following light resistance exercise with partial vascular occlusion and moderately difficult resistance exercise without occlusion. J Appl Physiol. 2006;101(6):1616-22. https://doi.org/10.1152/japplphysiol.00440.2006

[7] Stecco C, Porzionato A, Lancerotto L, et al. Histological study of the deep fasciae of the limbs. J Bodyw Mov Ther. 2008;12(3):225-30. https://doi.org/10.1016/j.jbmt.2008.04.041

[8] Myers TW. Anatomy trains: Myofascial meridians for manual and movement therapists. Churchill Livingstone/Elsevier; 2014.

[9] Chaitow L. Somatic dysfunction and fascia's gliding-potential. J Bodyw Mov Ther. 2014;18:1-3. https:// doi.org/10.1016/j.jbmt.2013.11.019

[10] Guimberteau JC, Delage JP, McGrouther DA, Wong JKF. The microvacuolar system: How connective tissue sliding works. J Hand Surg (European Volume). 2010;35(8):614-22. https://doi. org/10.1177/1753193410374412

[11] Lawson CS, Downey JM. Preconditioning: state of the art myocardial protection. Cardiovasc Res. 1993;27(4):542-50. https://doi.org/10.1093/cvr/27.4.542

[12] Pang CY, Yang RZ, Zhong A, Xu N, Boyd B, Forrest CR. Acute ischaemic preconditioning protects against skeletal muscle infarction in the pig. Cardiovasc Res. 1995;29(6):782-8. https://doi. org/10.1016/S0008-6363(96)88613-5 
[13] Whiting WC, Zernicke RF. Biomechanics of musculoskeletal injury. Human Kinetics; 1998.

[14] Donatelli R. Normal biomechanics of the foot and ankle. J Orthop Sports Phys Ther. 1985;7(3):91-5. https://doi.org/10.2519/jospt.1985.7.3.91

[15] Cosby NL, Grindstaff TL. Restricted ankle dorsiflexion self-mobilization. Strength Condit J. 2012;34(3):58-60. https://doi.org/10.1519/SSC.0b013e31824526e8

[16] Fong C-M, Blackburn JT, Norcross MF, McGrath M, Padua DA. Ankle-dorsiflexion range of motion and landing biomechanics. J Athl Train. 2011;46(1):5-10. https://doi.org/10.4085/1062-6050-46.1.5

[17] Malliaras P, Cook JL, Kent P. Reduced ankle dorsiflexion range may increase the risk of patellar tendon injury among volleyball players. J Sci Med Sport 2006;9(4):304-9. https://doi.org/10.1016/j. jsams.2006.03.015

[18] Macrum E, Bell D, Boling M, Lewek M, Padua D. Effect of limiting ankle-dorsiflexion range of motion on lower extremity kinematics and muscle-activation patterns during a squat. J Sport Rehabil. 2012;21:144-50. https://doi.org/10.1123/jsr.21.2.144

[19] Hewett TE, Myer GD, Ford KR, et al. Biomechanical measures of neuromuscular control and valgus loading of the knee predict anterior cruciate ligament injury risk in female athletes: A prospective study. Am J Sports Med. 2005;33(4):492-501. https://doi.org/10.1177/0363546504269591

[20] Griffin LY, Albohm MJ, Arendt EA, et al. Understanding and preventing noncontact anterior cruciate ligament injuries: A review of the Hunt Valley II Meeting, January 2005. Am J Sports Med. 2006;34(9):1512-32. https://doi.org/10.1177/0363546506286866

[21] Tabrizi P, McIntyre W, Quesnel M, Howard A. Limited dorsiflexion predisposes to injuries of the ankle in children. J Bone Joint Surg. 2000;82-B:1103-6. https://doi.org/10.1302/0301-620X.82B8.0821103

[22] Ross S. The Effects of 'tack and floss' active joint mobilisation on ankle dorsiflexion range of motion using Voodoo Floss Bands. 2017.

[23] Kiefer BN, Lemarr KE, Enriquez CC, Tivener KA, Daniel T. A pilot study: Perceptual effects of the Voodoo Floss Band on glenohumeral flexibility. International Int J Athl Ther Train. 2017;22(4):29-33. https://doi.org/10.1123/ijatt.2016-0093

[24] Driller MW, Overmayer RG. The effects of tissue flossing on ankle range of motion and jump performance. Phys Ther Sport. 2017;25:20-4. https://doi.org/10.1016/j.ptsp.2016.12.004

[25] Borda J, Selhorst M. The use of compression tack and flossing along with lacrosse ball massage to treat chronic Achilles tendinopathy in an adolescent athlete: a case report. J Man Manip Ther. 2017;25(1):57-61. https://doi.org/10.1080/10669817.2016.1159403

[26] Philip JS, Richelle KS, Kyle WD. Acute effects of the Voodoo Flossing Band on ankle range of motion. J Med Biomed App Sci. 2019;7(6). https://doi.org/10.15520/jmbas.v7i6.190

[27] Driller M, Mackay K, Mills B, Tavares F. Tissue flossing on ankle range of motion, jump and sprint performance: A follow-up study. Phys Ther Sport. 2017;28:29-33. https://doi.org/10.1016/j. ptsp.2017.08.081

[28] Mills B, Mayo B, Tavares F, Driller M. The effect of tissue flossing on ankle range of motion, jump and sprint performance in elite rugby union athletes. J Sport Rehabil. 2019:1-18. https://doi.org/10.1123/ jsr.2018-0302

[29] Hodeaux K. The Effect of floss bands on elbow range of motion in tennis players. Theses and Dissertations 2017. https://scholarworks.uark.edu/etd/1948

[30] Reid A, Birmingham T, Alcock G. Efficacy of mobilization with movement for patients with limited dorsiflexion after ankle sprain: A crossover trial. Physiother Can. 2007;59:166-72. https://doi. org/10.3138/ptc.59.3.166

[31] Vicenzino B, Branjerdporn M, Teys P, Jordan K. Initial changes in posterior talar glide and dorsiflexion of the ankle after mobilization with movement in individuals with recurrent ankle sprain. J Orthop Sports Phys Ther. 2006;36(7):464-71. https://doi.org/10.2519/jospt.2006.2265

[32] Konor MM, Morton S, Eckerson JM, Grindstaff TL. Reliability of three measures of ankle dorsiflexion range of motion. Int J Sports Phys Ther. 2012;7(3):279-87. 